\title{
COVID-19: Crisis e Incertidumbre
}

\begin{abstract}
PhD. Carina Viviana Ganuza
Pontificia Universidad Católica Argentina, Santa María de los Buenos Aires, UCA

carinaganuzatagliarini@gmail.com

Rosario, Argentina

https://orcid.org/0000-0002-8088-3741
\end{abstract}

\section{Editorial}

In memoriam al Arq. Alejandro Miguel Camino Solórzano (1957-2021).

Rector de la Universidad Laica "Eloy Alfaro" de Manabí, Ecuador.

La publicación del presente número, está dirigido al impacto del COVID19 en la vida humana, desde su irrupción a partir de diciembre del año 2019 en la ciudad de Wuhan (China) y su propagación en América del Sur desde marzo del año 2020. Para la perspectiva de análisis de todos los ciudadanos suramericanos, nos era imposible esta irradiación viral, sin embargo, atónitos advertimos desde marzo del año 2020, cuando un plan sistemático de aislamiento se implementó de manera gradual en cada uno de los países a nivel global. Las noticias diarias e informes sobre enfermos, recuperados y muertos, generaron dudas sobre dudas y así se hicieron extensivas con el devenir de los meses hasta la apertura gradual de las actividades.

Muchos de los gobiernos adoptaron medidas inicialmente proteccionistas, otros priorizaron sus economías; sin embargo, decisiones excepcionales que parecieran rondar el autoritarismo en muchos casos, no hacen más que coartar las libertades individuales, aunque amparadas en decretos presidenciales.

Las cifras informadas sobre la cantidad de enfermos o posibles casos, según el Sistema Integrado de Información Sanitaria Argentino (SISA, 2020): se han puesto en duda; muchas de las personas internadas en los centros de salud fueron diagnosticas con COVID-19 por protocolo, estén o no enfermas, como lo indica Organización Mundial de la Salud (OMS, 2019): otras han fallecido sin posibilidad de ser despedidas por sus familiares por temor al 
"contagio" y por otro lado, se han organizado reuniones masivas para dar el último adiós a un ídolo del fútbol como el inolvidable futbolista y entrenador argentino Diego Armando Maradona (1960-2020).

Tesis y antítesis, caras y contracaras de una misma situación, el COVID-19 no hizo más que exponer las problemáticas de exclusión, contradicciones, marginalidad, aislamiento, perversión como desigualdades ya subyacentes en cada individuo como en cada sociedad a nivel mundial.

Nada de lo existente en nuestra aldea global, tan rica y a su vez tan pobre de valores morales, se ha modificado en realidad, porque la crisis desatada por el virus SARS-CoV-2 solo se ha instalado para exacerbar especialmente, los rechazos ya disfrazados y las prácticas de exclusión hacia aquellos que parecen vivir, pero no pertenecer al círculo del sistema capitalista, por ejemplo, los sectores pobres, inclusive medios bajos y los ancianos.

La pretensión de análisis incipiente se ha desarrollado teniendo en cuenta cuestiones vertebrales: el término crisis, por la presencia del COVID19 y la incertidumbre como su desencadenante, afectando todos los aspectos de la vida humana. Por último, se han realizado conclusiones preliminares para un tema de debate y controvertido, que no está acabado y que sufre mutaciones con el devenir de las horas; y más si se tiene en cuenta la corta extensión de este trabajo.

El significado otorgado por la Real Academia Española (RAE, 2020a): al término crisis, hace alusión a un cambio profundo y de consecuencias importantes, de esta forma se puede entender que el COVID-19 ha generado una transformación en la visión y en la forma de pensar la vida, ya que si bien, cada uno de nosotros somos conscientes de nuestra propia finitud, nos agrade o no; este virus de origen desconocido hasta la fecha, ha instalado la idea de la muerte en el imaginario colectivo y se ha arraigado de una manera brutal; está al acecho y latente, flotando... Tal es así, que pueden verse personas con 
barbijos en sus propios automóviles y encerrados en sus inmuebles, con el rostro cubierto, como si la peste estuviese escondida dentro de sus casas.

Al reflexionar sobre la crisis desatada por el COVID-19, nos referimos a una alteración en la concepción de la existencia y en la vida misma, en los sistemas sanitarios y educativos y en paralelo, a la instalación del concepto de incertidumbre como una especie de circunstancialidad; ya que, si bien todos sabemos de la presencia de la muerte, el virus protagónico del año 2020, generó esta suerte de imprevisión. Irrumpió para la mayoría de los mortales ciudadanos, aunque seguramente no para muchas autoridades nacionales que si conocían de su existencia.

Crisis e incertidumbre se han ensamblado; cualquier enfermoconvaleciente que haya sobrevivido a la experiencia de la internación en cualquier centro sanitario puede dar testimonio de ello; alguno de los tantos ciudadanos despedidos de su trabajo en plena pandemia desde abril del año 2020 por el gobierno ecuatoriano, podrían dar fe de esto o los desempleados en Argentina "contenidos" con planes asistenciales momentáneos y de urgencia como en toda la historia de este país; y así sería interminable la lista a nivel mundial.

Al definir incertidumbre, para la Real Academia Española (RAE, 2020b): también puede comprenderse su significado como la falta de seguridad, de confianza o de certeza; ante esto, nadie es más culpable que los propios medios de comunicación que de una forma sistemática han exacerbado el pánico y generando terror, al más simple ciudadano como a cualquier profesional, sin hacer distinción de formación académica o título. Todos nos hemos visto obligados a recurrir a diversas fuentes de información excepto, los canales de televisión que bajo titulares dantescos como catastróficos no hicieron y hacen, más que remarcar al COVID-19 y la muerte como su consecuencia casi inminente. Acorde con el filósofo coreano Han (2020a): "Sobrevivir se convertirá en algo absoluto, como un estado de guerra 
permanente" (pág. 1).

En este sentido, Han (2020b): ya ha expuesto su temor respecto a la pandemia y su posible uso como arma biopolítica para la imposición de regímenes de vigilancia y cuarentenas, pérdida de libertad, inclusive la falta de humanidad, generada en gran parte, por la histeria y el miedo colectivo. Lamentablemente todo esto se ha cumplido, si no basta con observar los centros de "asistencia" en la ciudad de Formosa (provincia homónima de Argentina) donde decenas de personas han sido privadas de su libertad; $y$ ante lo cual, la Procuraduría de Violencia Institucional (PROCUVIN), ha intervenido por las denuncias de abusos cometidos en estos supuestos centros de atención y aislamiento.

En este aspecto, Sayeh y Chami (2020): agregan que "la pandemia de COVID-19 amenaza con agotar una fuente vital de ingresos de los países pobres y frágiles" (pág. 16); dejando a su paso, una vista de que la vulnerabilidad o mortalidad humana, no es autoritaria, sino que depende del estado social. La pandemia, pone de realce las dificultades generales, los fallos y las discrepancias de cada sociedad.

La incertidumbre consecuente por la existencia del COVID-19 es una premisa inobjetable; las realidades vividas en los diferentes puntos del globo terráqueo adquieren distintas formas. En China, ningún aspecto ha escapado al control gubernamental; la vigilancia social produce un intercambio de datos y casi o es inexistente su protección, en términos occidentales, de la propiedad y vida privada.

Cada ser humano se ha acomodado a esta realidad modificada por la presencia de un virus intangible e invisible a nuestros ojos, los niños, adolescentes y los adultos en cada tarea diaria. Los sistemas informáticos y la velocidad de internet se han convertido en ejes esenciales para el desarrollo de nuestras actividades en cada domicilio. ¿Pero qué ha sucedido con aquellos que no estaban preparados para experimentar este proceso de 
adaptación? Algunos han perecido y otros estarán sumidos en crisis donde solo el tiempo exhibirá sus consecuencias.

Muchos de los estudiantes en sus diferentes niveles de preparación han carecido de los insumos necesarios para poder desarrollar las clases virtuales, si bien porque carecen de los medios, ya sean computadoras, teléfonos o bien, internet y otros también, porque no lo han deseado. Los docentes se vieron obligados a "poseer" todos los servicios para brindar educación a sus alumnos, continuar con sus clases, culminar prácticas curriculares.

La pregunta que nos realizamos es ¿qué ley ha establecido que el docente "debe" gozar-pagar internet y tener la computadora último modelo con velocidad suficiente para hacerse cargo de todas las clases y de todos los alumnos? Ningún gobierno ha respondido a esto, al menos en Suramérica. Ningún gobierno se responsabilizó se ha responsabilizado de ello. Se han criticado a los profesores por "dudar de dictar clases en forma presencial", pero ningún ciudadano sabe sobre los sacrificios y horas que se necesitan para poder afrontar esta situación, que hasta el momento no parece solucionarse.

Crisis e incertidumbre se ciernen sobre la vida humana en distintos puntos de la esfera mundial. Cambios económicos, sanitarios, educativos, inestabilidad, a veces desasosiego y muchas veces, una lista interminable de preguntas ontológicas que algún día quizás puedan ser respondidas. Solo el tiempo nos permitirá evaluar una salida ante esta irrupción invisible, pero férrea que ha modificado nuestras vidas.

Palabras clave: crisis; incertidumbre; covid-19; editorial.

Fecha de Recepción: 04-09-2020
Fecha de Aceptación:

18-12-2020
Fecha de Publicación: 05-02-2021 


\section{COVID-19: Crisis and Uncertainty}

\section{Editorial}

In memoriam to Arch. Alejandro Miguel Camino Solórzano (1957-2021). Rector of the Lay University "Eloy Alfaro" of Manabí, Ecuador.

The publication of this issue is aimed at the impact of COVID-19 on human life, since its emergence from December 2019 in the city of Wuhan (China) and its spread in South America since March 2020. From the perspective of analysis of all South American citizens, this viral irradiation was impossible for us, however, astonished we warned since March of the year 2020 , when a systematic isolation plan was gradually implemented in each of the countries globally. The daily news and reports on sick people, recovered and dead, generated doubts about doubts and thus they were extended with the passing of the months until the gradual opening of the activities.

Many of the governments initially adopted protectionist measures, others prioritized their economies; However, exceptional decisions that seem to be around authoritarianism in many cases do nothing more than restrict individual freedoms, although they are protected by presidential decrees.

The figures reported on the number of patients or possible cases, according to the Argentine Integrated Health Information System (SISA, 2020): have been questioned; Many of the people admitted to health centers were diagnosed with COVID-19 by protocol, whether or not they are sick, as indicated by the World Health Organization (OMS, 2019): others have died without the possibility of being fired by their relatives for fear of "contagion" and on the other hand, massive meetings have been organized to say goodbye to a soccer idol such as the unforgettable Argentine soccer player and coach Diego Armando Maradona (1960-2020).

Thesis and antithesis, faces and counterparts of the same situation, COVID-19 did nothing more than expose the problems of exclusion, contradictions, marginality, isolation, perversion as inequalities already 
underlying each individual as well as each society worldwide.

Nothing that exists in our global village, so rich and at the same time so poor in moral values, has actually been modified, because the crisis unleashed by the SARS-CoV-2 virus has only been installed to especially exacerbate, the already disguised rejections and the practices of exclusion towards those who seem to live, but do not belong to the circle of the capitalist system, for example, the poor sectors, including the lower middle and the elderly.

The pretense of incipient analysis has been developed taking into account vertebral issues: the term crisis, due to the presence of COVID-19 and uncertainty as its trigger, affecting all aspects of human life. Finally, preliminary conclusions have been made for a controversial and debated topic, which is not finished and which undergoes mutations with the passing of time; and more if the short extension of this work is taken into account.

The meaning given by the Royal Spanish Academy (RAE, 2020a): the term crisis refers to a profound change and important consequences, in this way it can be understood that COVID-19 has generated a transformation in the vision and in the way of thinking about life, since although each of us is aware of our own finitude, whether we like it or not; This virus of unknown origin to date, has installed the idea of death in the collective imagination and has taken root in a brutal way; it is lurking and latent, floating... So much so, that people with chinstraps can be seen in their own cars and locked in their buildings, with their faces covered, as if the plague were hidden inside their houses.

When reflecting on the crisis unleashed by COVID-19, we refer to an alteration in the conception of existence and in life itself, in the health and educational systems and in parallel, to the installation of the concept of uncertainty as a kind of circumstantiality; since, although we all know of the presence of death, the leading virus of the year 2020, generated this kind of unforeseen event. It broke in for the majority of mortal citizens, although surely not for many national authorities who did know of its existence. 
Crisis and uncertainty have joined; any patient-convalescent who has survived the experience of hospitalization in any health center can bear witness to it; Some of the many citizens fired from their job in the middle of the pandemic since April 2020 by the Ecuadorian government, could attest to this or the unemployed in Argentina "contained" with momentary and emergency assistance plans as in the entire history of this country; and so the list would be endless worldwide.

When defining uncertainty, for the Royal Spanish Academy (RAE, 2020b): its meaning can also be understood as the lack of security, trust or certainty; Faced with this, no one is more guilty than the media themselves, which have systematically exacerbated panic and generated terror, to the simplest citizen as well as to any professional, without making a distinction of academic training or title. We have all been forced to resort to various sources of information except, the television channels that under dantesque and catastrophic headlines did not do and do, rather than highlight COVID-19 and death as its almost imminent consequence. According to the Korean philosopher Han (2020a): "Survival will become absolute, like a permanent state of war" (p. 1).

In this sense, Han (2020b): has already exposed his fear regarding the pandemic and its possible use as a biopolitical weapon for the imposition of surveillance regimes and quarantines, loss of freedom, including the lack of humanity, generated in large part, by hysteria and collective fear. Unfortunately, all this has been fulfilled, if it is not enough to observe the "assistance" centers in the city of Formosa (province of the same name in Argentina) where dozens of people have been deprived of their liberty; and before which, the Office of the Institutional Violence Prosecutor (PROCUVIN), has intervened for the complaints of abuses committed in these supposed care and isolation centers.

In this regard, Sayeh and Chami (2020): add that "the COVID-19 
pandemic threatens to deplete a vital source of income in poor and fragile countries" (p. 16); leaving in its wake a view that human vulnerability or mortality is not authoritarian, but depends on social status. The pandemic highlights the general difficulties, failures and discrepancies of each society.

The consequent uncertainty due to the existence of COVID-19 is an unobjectionable premise; the realities experienced in different parts of the globe take different forms. In China, nothing has escaped government control; social surveillance produces an exchange of data and its protection, in Western terms, of property and private life is almost or non-existent.

Every human being has accommodated himself to this reality modified by the presence of an intangible and invisible virus to our eyes, children, adolescents and adults in every daily task. Computer systems and internet speed have become essential axes for the development of our activities in each home. But what has happened to those who were not prepared to experience this adaptation process? Some have perished and others will be mired in crisis where only time will show its consequences.

Many of the students in their different levels of preparation have lacked the necessary inputs to be able to develop virtual classes, although because they lack the means, be it computers, telephones or, internet and others as well, because they have not wanted it. Teachers were forced to "own" all the services to provide education to their students, continue with their classes, complete curricular practices.

The question we ask ourselves is what law has established that the teacher "must" enjoy-pay for the internet and have the latest model computer with enough speed to take care of all the classes and all the students? No government has responded to this, at least in South America. No government has taken responsibility for it. Teachers have been criticized for hesitating to teach classes in person, but no citizen knows about the sacrifices and hours it takes to face this situation, which so far does not seem to be solved. 
Crisis and uncertainty loom over human life at different points in the world sphere. Economic, health, educational changes, instability, sometimes uneasiness and many times, an endless list of ontological questions that one day may perhaps be answered. Only time will allow us to evaluate a way out of this invisible, but iron, irruption that has modified our lives.

Keywords: crisis; uncertainty; covid-19; editorial.

Date Received: 04-09-2020
Date Acceptance:

18-12-2020
Date Publication: 05-02-2021 


\section{Referencias}

Han, Byung-Chul (2020). Byung-Chul Han Analiza la Pandemia. Argentina:

Idep Salud.

OMS (2019). Orientaciones técnicas sobre el nuevo coronavirus (2019-

nCoV). Ginebra; Suiza: Organización Mundial de la Salud.

RAE (2020a). Crisis. 23. ${ }^{a}$ edición. Madrid, España: Real Academia Española.

Recuperado de: https://dle.rae.es/crisis

RAE (2020b). Incertidumbre. 23. ${ }^{\text {a }}$ edición. Madrid, España: Real Academia

Española. Recuperado de: https://dle.rae.es/incertidumbre

Sayeh, A., \& Chami, R. (2020). Una forma de sustento en peligro. Finzas y Desarrollo, 57(2), 16-19, e-ISSN: 0145-1707. Washington, Estados Unidos: Fondo Monetario Internacional (FMI).

SISA (2020). Informe SISA: Desarrollos relevantes implementados en 2020. Argentina: Dirección Nacional de Gobernanza e Integración de los Sistemas de Salud; Sistema Integrado de Información Sanitaria Argentino. 


\section{Carina Viviana Ganuza}

e-mail: carinaganuzatagliarini@gmail.com

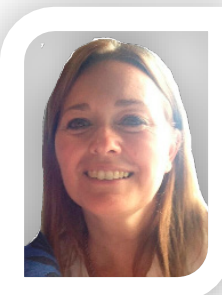

Nacida en Rosario, Santa Fe, Argentina, el 7 de abril del año 1971. Doctora en Ciencia Política (UCA), Buenos Aires; Magister en Integración y Cooperación Internacional de la Universidad Nacional de Rosario (UNR); Profesora de Historia y Postítulo en Historia Social, entre otros estudios de formación específicos interdisciplinarios (CELAG);

Coordinadora y docente de postgrado (UNR), en la Universidad Adventista del Plata y la Universidad Nacional de Educación (UNAE), Ecuador; Coordinadora de aseguramiento de la calidad de la Universidad de Lovaina (UCLouvain); Desarrollo actividades de investigación como directora en temas de política económica del Ecuador y a nivel suramericano; miembro del Centro de Estudios de Relaciones Internacionales de Rosario (CERIR) y del Comité Académico Científico de Revistas de Investigación en Ecuador.

El contenido de este manuscrito se difunde bajo una Licencia de Creative Commons ReconocimientoNoComercial-Compartirlgual 4.0 Internacional 